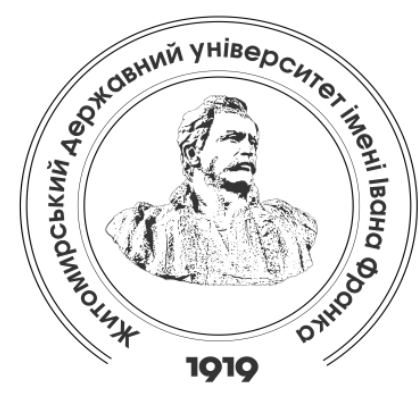

Zhytomyr Ivan Franko State University Journal. Philosophical Sciences. Vol. 1(87)

Вісник Житомирського державного університету імені Івана Франка. Фімософські науки. Вип. 1(87) ISSN: $2663-7650$

\title{
PEAIГIEЗHABCTBO
} RELIGIOUS STUDIES

\section{UDC 246.6.001.32(045) \\ DOI 10.35433/PhilosophicalSciences.1(87).2020.5-14 \\ TENDENCIES OF DESACRALIZATION AND SYMBOLISM IN SPIRITUAL CULTURE THROUGH THE PRISM OF MODERNITY CHALLENGES}

\author{
P. Yu. Saukh, M. S. Melnichuk*
}

The article explores the reasons for the leveling of spiritual Christian values against the background of the modern world. This scientific exploration demarcates the concepts of desacralization and resacralization in the cultural and artistic space of today. It is found that the process of resacralization becomes possible due to the deep archetypes of human consciousness, which replaces the sacred, which has become in modern culture an empty simulacrum. It is outlined that the spiritual culture of today characterized by an increase in its crisis.

The author of the article emphasizes that due to the loss of all values, cultivation of hedonistic individualism in customs, disintegration of sexual morality, triumph in tastes and ideals of eclecticism, the destructive influence of market relations leads to the replacement of spiritual ideals of the past by today's interests. It is emphasized that in art there is pure aesthetics, pure pointlessness and such non-utilitarian art, freedom from any social, ethical or religious involvement, lack of spirituality and morality, aimed only at aesthetic pleasure (pleasant emotional state, pleasant pleasure, feeling), leads to the infinite spirituality of art, and, consequently, to the death of high art, which in the second half of the twentieth century pours into the art activity, abandoned the brush, paints, canvas. It is traced that in art at this time there is a complete rejection of the aesthetic category of beauty and there is a cult of the ugly, there is a dehumanization of art. Denial of imagery by the avant-garde leads to the replacement of a painting or sculpture by a real object (pop art, ready-made), and Dadaism denies all spiritual values, laws of morality, ethics, religion, assertion of chaos and arbitrariness, unbridled nihilism and hysterical overthrow of all morality.

${ }^{*}$ Doctor of Sciences (Philosophy), Professor, Academician of the NAES of Ukraine, Academiciansecretary of Department of Higher Education (National Academy of Educational Sciences of Ukraine, Kyiv, Ukraine)

ukr_filosof@ukr.net

ORCID: 0000-0003-4366-2496

Candidate of Philosopchical Sciences, Associate Professor

(National UniversityofWaterandEnvironmental Engineering, Rivne, Ukraine)

m.s.melnuchyk@nuwm.edu.ua

ORCID: 0000-0002-4299-968X 
It was found that against the background of such transformations, art should become a game and a pleasure, give up heritage, should destroy oppressive values, release vital energy, lead to wild and deep pleasure, is "free from culture to return to what was animal, primitive". Due to this, sprouts of anti-culture, happening, pornography and cyber shamanism appeared. An attempt is made to identify the causes of traditional desacralization and the emergence of new sacred and religious symbols in today's postmodern conditions.

Keywords: Desacralization, Resacralization of Art, Spiritual Values, Leveling of the Sacred, Postmodern, Cyber Shamanism, Uncertainty.

\title{
ТЕНДЕНЦІї ДЕСАКРАМІЗАЦІї І СИМВОАІЗМУ В ДУХОВНІЙ КУАЬТУРІ КРІЗЬ ПРИЗМУ ВИКАИКІВ СУЧАСНОСТІ
}

\author{
П. Ю. Саух, М. С. Мемьничук
}

У статті досліджуються причини нівеляиї духовних християнських иінностей на тлі осучаснення світу. Авторами експлікуються поняття десакралізації та ресакралізації у культурно-мистеиькому просторі сучасності. Виявлено, шо проиес ресакралізаиіi стає можливим завдяки глибинним архетипам людської свідомості. Він заміняе сакральне, шо стало у сучасній культурі порожнім симулякром. Окреслено, шо духовна культура съогодення характеризуеться наростанням у ній кризових явищ. Завдяки втраті позитивних иіннісних орієнтирів, культивації гедоністичного індивідуалізму в звичаях, занепаду сексуальних засторог моралі, панування у смаках $і$ ідеалах еклектики, руйнівний вплив ринкових відносин призводить до заліни духовних ідеалів минулого інтересами утилітарного, меркантильного сьогодення.

Доведено, шуо у мистеитві продукується чистий естетизм, ииста безпредметність $i$ неутилітарність мистеитва, свобода від будь-якої соиіальної, етичної або релігійної заангажованості, відсутність духовності і моральності, які мають на меті лише естетичну насолоду (приємний емоиійний стан, приємне задоволення, почуття), шо веде до нескінченної бездуховності мистеитва, $i$, отже, до смерті високого мистеитва, ио в другій половині XX ст. виливається в арт-діяльність, яка відмовилася від пензля, фрарб, полотна. Прослідковано, що у мистеитві в ией час відбуваеться відмова від естетичної иінності краси і продукуеться культ потворного, відбувається дегуманізаиія мистеитва. Заперечення зображальності авангардом веде до заміни картини або скульптури реальним предметом (поп-арт, редимейд), а в дадаїзмі відбувається заперечення всіх духовних иінностей, законів моралі, етики, релігї̈, ствердження хаосу і свавілля, нестримний нігілізм та істеричне повалення всіх основ моральності.

На тлі таких трансформаиій мистеитво фрактично перетворюється в гру $і$ насолоду, відмовляеться від спадщини, трансрормуе иінності, "вивільняе життеву енергію та приводить до дикого і глибокого задоволення". Звідси паростки антикультури, хепенінгу, порномистецтва та кібершаманізму. В иьому контексті у статті здіснено спробу виявлення причин десакралізаиї̈ традииійних духовних, релігійних иінностей та появи якісно нових сакральних символів в умовах постмодерну.

Ключовіслова: десакралізація, ресакралізація мистеитва, духовні иінності, нівеляція сакрального, постмодерн, кібершаманізм, невизначеність.

\begin{tabular}{|c|c|}
\hline $\begin{array}{l}\text { Introduction of the issue. The } \\
\text { principle of desacralization can be } \\
\text { considered as the specifics of the } \\
\text { existence of modern culture, as the } \\
\text { ontological basis of modern postmodern } \\
\text { culture. This characterizes the } \\
\text { devaluation of sacred models, the loss of }\end{array}$ & $\begin{array}{l}\text { the transcendental reality of } \\
\text { general and art in particular. } \\
\text { to the loss of what ensures } \\
\text { integrity of culture, the worl } \\
\text { man, and as a consequ } \\
\text { decentralization of culture, } \\
\text { and non-hierarchy of value } \\
\text { postmodern culture conscious }\end{array}$ \\
\hline
\end{tabular}


an essential level refuses to recognize the existence of any other spiritual principle - God. The exception is the mundane human, devoid of any focus on irrationality ideals and metaphysical realities.

The emphasis on the importance of the religious and spiritual component in the life of the modern human community in general and Ukraine in particular, which has intensified against the background of awareness of the leveling of traditional Christian spiritual values today, in itself produces a number of issues that require rethinking, reassessing or even reassessing. These problems include the search for reasons for the desacralization of modern spiritual culture in the context of the dictates of the realities of modernity, postmodern content and the imperative of the moral and spiritual cores of modern society. To some extent, the problems of the sacred in the spiritual culture of today, the leveling of spiritual values of today in different contexts have been studied in the works of R. Otto, M. Eliade, A. Leshchenko, A. Safonova, V. Bychkov, A. Bonnet, J. Poetter and many other theologians, philosophers and art critics.

The purpose of the study is to identify the phenomenon of the sacred in modern desecrated culture that can realize the process of sacralization in the culture and art of today and prove that the process of re-sacralization is possible due to the connection of the sacred with the deep archetypes of human consciousness.

Results and discussion. The sacredspiritual principle is essentially ontological for man, so the idea of it has acquired a wealth of polyphony of scientific approaches as a result of a number of explorations and research. The problems of sacred symbolism, despite the antiquity of its origin, are relevant to modern man. They have adopted somewhat different new forms of expression in modern reality, acting as a personally experienced factor in the integrity of man and the world. A. Leshchenko, for example, understands the sacred symbol "a sacred sign of material or figurative origin. It is the unity of matter, information and energy and contains in a concentrated and orderly form energetically rich information about the irrational and transvirtual idea of God-man attractive to man in its meaning of life" [1: 238]. A. Safonova considers the sacred as an archetype, a subconscious symbol that has an impact on people and is projected on objects and phenomena of reality, forcing the individual's psyche to go beyond the human, where there is an encounter with the sacred. In this case, "the area of objects to be sacralized at different stages of social development and in different cultural traditions, is quite extensive and defined only functionally - the connection of the sacralized with any deep archetype that is the source of value meanings" [2: 9]. That is, sacralization can unfold in two principal forms of existence - as "sacredreligious" (traditional), the ontological basis of which is "rooted" in the transcendent, supernatural, as well as "sacredly secular" (non-traditional), in the ontological basis of which the human, the everyday, which is brought to the absolute, and, consequently, everything is subject to sacralization from the highest metaphysical principle to the object of life.

Each cultural epoch presupposes its own object of sacralization, which can be, for example, religious values, moral values, spiritual or, as modern practice shows, anti-spiritual values. The modern process of resacralization is expressed, according to $\mathrm{M}$. Eliade, in the desire of man to regain the "sacred space"."The process of desacralization deprived art of high spirituality (high sacred sacred 
images, so to speak, became commonplace), and it began to appeal to the lower archaic, shamanic, archetypal, pagan strata of culture" [3: 134], because the human imagination is impossible without symbolism and continues to live in the present archaic myths. Today, the traditional notion of the sacred is replaced by its simulacrum. This stimulates the emergence of new sacred symbols that correspond to the situation of postmodern society, which emerged as a result of socio-cultural uncertainty. In modern culture, the experience of the sacred corresponds to "many branches of discrete sacred spaces, in which the continuous process of sacralization within the post-secular society" [2:15]. Defining the signs of the sacred and its new features today, A. Savkina justifiably draws attention to the performativity, deobjectification and personalization of this phenomenon [11].

As a result of the simulation, simulacra of various kinds have now replaced the image and symbol of traditional arts. The essence, meaningful and semantic content of the work is not recognized by the current post-culture. And only appearances, "with their instantaneous somatic energies inspire the artist from now on, determine priorities on the art scene of the end of the XX - beginning of the XXI century" [4:68]. They form specific features of the process of re-sacralization, expressing the fact that the content has disappeared, leveled, there is only a soulless shell "yesterday" sacred, even numinous. The sacred, which was interpreted as an object of worship, lost its fundamental essence as a result of transformation (sometimes even mutations) and deconstruction of the entire culture in the twentieth century. From this phenomenon there is only an empty shell, visibility - a simulacrum. While the substantive part of the definition, related to the essential and spiritual, meaningful meanings, has been transformed and leveled. The spiritual, the absolute, the divine, revealed by God, simply ceased to exist, giving way to the unworthy, the ugly, the unspiritual, the sinful-corporeal. Since higher spiritual values and meanings have been lost, they become relevant and are replaced by others, lower, down to earth, who receive the right to exist, according to the principle of nonhierarchy and pluralism.

Desacralization as an apostasy of art and culture has led to the devaluation of aesthetic and spiritual cultural values. The consequence of this was that the sacred lost its former realm of definition - the higher spiritual world of the Divine. It has become a spiritless, empty simulacrum of modernity. It has spread in art to unconscious and unconscious phenomena, corporeality and sexuality, eroticism in various forms, and cruelty - sacralized already in a society of mass consumption. In addition to these changes as a result of modern cultural development, according to O. Ivanivska, there is a "shift of semantic accents of modernity from the secular ("profane") worldview towards the occult-magical and mystical-esoteric perception of reality. In addition, there is a shift in the focus of religiosity itself from collective ritual practices to individual problems of the meaning of esoteric systems" [5:34]. Therefore, "shamanism" and "shamanic practices" became relevant in the art of the twentieth century. It is an attempt to find at that time a long-lost way to the sacred, secret, which facilitates travel to other realities. Travel is inaccessible to the uninitiated, through which the artist tries to go beyond his self, his "I" and gain transcendent experience.

The art of the twentieth century is understood as a sacred practice, beginning with the theosophical search for the national avant-garde, happening 
as almost shamanic rituals, and ending with the "cyber-shamanism" of modern media art. Even the avant-garde and the art of modernism chose as a model not classical formulations, but earlier mystical and esoteric cult forms. This justifies the sacralization of artistic craft. The formula "shaman artist" was common to describe a variety of phenomena. In particular, V. Kandinsky defined the main condition of true creativity "the search for points of contact between the spiritual and material world", which was for him an important involvement in the "universal root of existence, the mystical origin" [6: 129]. K. Malevich's Suprematism and V. Kandinsky's abstractionism are all attempts to comprehend transcendent images of higher existence.

The most important, in our opinion, in this complex process was the influence of those theosophical ideas. They became a breeding ground for the theme of mystical knowledge of God, contemplation of God, in the light of which the secret knowledge of all things was revealed. In this context, J. Boyce, an artist of ritual gesture, stands out. In performances and actions, he performed magical actions with objects that had a symbolic meaning for him. Another wellknown "shaman" in the modern art elite is the postmodernist J. Kunellis. Instead, J. Pollock in 1948 in the gallery "Art of this century" demonstrated his new work is not a new technique of dripping. He sprayed paint on the canvas, just as Indian shamans sprayed sacrificial blood on the ground. "Painting of action" by J. Pollock returned to "actual practice a ritual gesture of invocation of divine energy, the spirit of the native land" [7: 71]. It is interesting to note that in 1989 J.-Y. Martin made a combination in his "exposition of modern radical culture and the archaic imagery of the shamanic cult". And R. Smithson, one of the most famous representatives of land art, all his creative life was occupied with the idea of "returns the prototype of the Earth, return it to an organic state... The artist, perceiving it as a cut, ulcerated creature, constantly tries to heal this creature by making magical movements over its surface" [8: 136-138]. Some artists, such as G. Vinogradov, perform mysteries, where there is work with the elements of fire, air and water, which is no longer surprising. After all, the sacred world includes all "spiritual activity of man, the energetic manifestation of his personality" [9: 154]. In his opinion, the artist as the Creator: without the sacred cannot, otherwise he ceases to be (creator) artist.

"Religious Renaissance", not without reason, is also associated by O. Ivanovskaya with the "virtualization of the cultural space" of modernity, which generates an alternative "creative-mental reality" [5:34]. Thus, the traditional spiritual world of culture is successfully compensated by the virtual electronicdigital world of post-culture, created by the efforts of man himself with the help of scientific and technological achievements of avant-garde modernist art of the twentieth century. The rationalist rejection of the Divine First Principle and the Absolute, in practice, results in a relentless search for traces of the Spiritual in the digital cyberspaces of the modern world. With the emergence of the Internet as a social phenomenon, in 2001 the development of cyber-shamanism is characterized by the emergence at the junction of the real and virtual worlds of a specific "third reality". In the discourse based on modern means of communication "Teterinmultimodeliness (the work of media artist Sergei Teterin the authors) is similar to the device of the magical space, and the total connection for the wizard of the electronic village performs the functions of spiritual vision" [7: 67]. 
Incidentally, the search for the sacred is also becoming characteristic of mass media art. Bright personalities became stars thanks to photography and mass media. The reason for this was mass culture, which articulates collective desires. In the "star" the figures of liberation and identification intersect. "As a result of their personal achievement and social influence they began to be admired (admired), identification with them allowed to compensate for the deficit of feelings felt in the mass (alienation, loneliness)" [10: 112]. These cult figures became for ordinary mortals like gods. "The Virgin portrayed with her vulnerability a special case in relation to the star, a profane version of a Christian martyr. In her "image", which threatened to destroy the real soul (for example, M. Callas and M. Monroe), fused real personality and fictitious figure; it was an artificial product with a natural essence... The star, respectively, Virgo is an icon and a sign (symbol) of the mass-media society of consumption; it acquired an exchange value due to the medial system" [10: 113]. Such a media star and cult figure was, for example, E. Warhol, who cultivates pop art. And what began as a demystification of the genius artist $\mathrm{E}$. Warhol, ended with the enthronement (throne) of the artist as a cult figure. In turn, J. Boyce also referred to his image as "the art of iconography".

Modern contemporary and conceptual art has manifested the essential transformation of the traditional understanding of the sacred to zero (annihilation) and the introduction into the "relevant" sphere of sacred other content, previously, was not even taken into account. Similar tendencies arose on the basis of Nietzscheanism, Freudianism, existentialism, structuralism and postmodernism. In this respect, "absurdity", "cruelty", "mundaneness", "corporeality", "cult of things", "simulacrum", "gesture", and "sexuality", and others become the artistic "norm". As noted by A. Savkina, "modern art, as a clear traditional idea of the sacred, and simulating the traditional experience of the sacred, reflects the desire to know the sacred reality, but more often it is no longer on the basis of religion as a social institution, but in the process of individual experience" [11:20]. And as a result of this individual experience in modern art there is a sacralization not of spiritual, but of anti-spiritual bodily, sexual, aggressive phenomena. There is a transgression of cultural conventions and the experience of sexuality, violence, death as sources of modern sacralization and the truth of life in the perspective of postmodern society.

Many currents of modern art are advancing along the paths of awakening and actualization of the somatic Dionysian element, which are being released against the background of modern technogenic civilization. As a result, the human consciousness feels emptiness and "nothing" instead of a stable and reliable highly spiritual space around it or, in the words of V. Bychkov, some "discomfort of abandonment of God" [4]. The whole tragedy of this cosmic or even metaphysical loneliness and alienation of modern man is expressed in the twentieth century in the peculiar works of philosophers and existentialist writers.

From the middle of the twentieth century, the abyss of spirituality and emptiness began to be filled by the products of the so-called post-culture. $\mathrm{He}$ is trying to restore the lost Divine pole of spirituality through the acquisition of "another" already here on Earth. Nietzsche's assertion of emancipation of the body, bodily intuitions (the body and the body itself must "dictate" and determine everything in human life), instinct, a return to a full, 
unfettered by any conventions of physiological life. It is based only on instinct and a deep optimistic will to live, stimulated the emergence of art, in which the simulacra of the sacred corporeal fill the traditional sacredness of the spiritual, claiming reality. As a result, "... the artist of post-culture often brings to the fore aggressive instincts and sexual desires, exerting a strong influence on his art activities. Hence the sensual eroticism (which often reached the demonstrative porn) and the ostentatious apotheosis of sadism, masochism, aggression, cruelty"[12: 86]. There is an active inclusion of the sphere of cruelty in one's own aesthetic experience, that is, the aestheticization of the representation of cruelty (example: G. Nitch and his "Orgy and Mystery Theater"). Photography and media art promote the cult of the body, but this cult of body and beauty is a subversive (destructive) strategy. All those "lures" that catch up with us due to the involvement of the beauty industry and fashion stores, work with a seductive glow of glamor, as well as hidden appeals that are concerned about our libidinal sensory subconscious. Such strategies began to be strengthened by artists. Never before, since the beginning of the avant-garde, has beauty been able to bring its superficial appeal to such free expression [13: 228]. A rather powerful flow of presentation of both violence and cruel acts in modern elite and mass art has led to the fact that the concept of corporeality has become one of the significant creative and stimulating principles of post-culture, forming as a kind of antithesis of the concept of spirituality. The artistic search for artists of a postmodernized society has finally lost the ability to be a link, a mediator between man and the Spiritual, Divine world. Artists have ceased to address the highly spiritual, the divine, to carry and contain this principle. Becoming a simulacrum, the sacred began to fill art not with high and spiritual absolute values, but with mundane, completely human phenomena, through which the artist, it seems to him, finds the experience of the transcendent. Thus, all modern art offers a total simulative practice, when everything can be different, but nothing can be itself. Therefore, sometimes "it seems that we return either to the aesthetic Middle Ages or to the early forms of polytheism, but in fact the mainstream, the mass media ideology of the crowd, wins" [8: 20].

In our opinion, desacralization should be considered as a category that has a worldview and signifies the loss of that transcendent property (knowledge of the Absolute, awareness of God, the connection of everything with everything). Possession of it placed, in any position of exceptional importance, special value and on this basis required a pious sacred attitude. Contemporary desacralized postmodern art focuses, as a rule, on everyday human and devoid of focus on any metaphysical ideals, metaphysical realities. Therefore, there is no need for many traditional aesthetic intermediaries between an ordinary earthly person and something superearthly, intangible. It is all "here and now - on earth, in the thick of man-made civilization and knows nothing but this" earth "and does not want to know" [4]. It is no coincidence that A. Bonnet, asking the question: is postmodernism an art or not?, answers in the affirmative, "yes!". Why? Because it meets its main criteria: it has both a sensory-contemplative form and a lack of interest in judging taste."However a new forms of this art, such as music videos, performances, shows, musicals, etc., characterize it as something temporary that has no future"[10].

In the plane of modernity, postmodern culture uses the category of corporeality to move creative thinking beyond 
transcendental subjectivity towards a kind of rehabilitation of sensuality in the form of ordinary sexual energy, to the limits of understanding corporeality, which is manifested in the "hypertrophied cultivation of bodily intentions and aspirations, touches and touches". V. Bychkov characterizes this as "libidinal drug consciousness", the key center of which is in a person "below the belt" [4]. Through this center, modern intellectuals of art express chthonic, Dionysian, unconscious intentions of human sensuality, which previously found a similar way out only in primitive folklore.In contemporary art, they are brought to their extreme "subtly-perverted embodiment" in verbal or visual images (J. Batay, W. Burroughs, V. Erofeev, V. Sorokin).

Such absolutization of the cultivation of corporeality, somatic experience, relentless concern in society for constant physical and especially energetic nourishment of the body gradually leads to the further movement of body-oriented art practices, when from a rough material carrier as a thing they have recently switched to a thinner, electronic (through computer-network reality with its virtual corporeality).As a result, "the combination of plots of violence, death and sex together with well-thought-out market strategies has a strong media response" [10: 139].

Postmodern culture and art have in fact put sexuality, as one of the physiological functions of the body, in place of the spirituality of traditional classical culture, philosophy, and Christian theology. Beginning with M. Foucault ("History of Sexuality"), sexuality began to be understood by postmodernists as one of the main components of life and consciousness of modern man, as the engine of all his intellectual and sensory activities, the main mediator between man and the world.The so-called libidinal energy flows are still in the spotlight of modern postmodern thinkers, who have determined the directions of EuroAmerican search for the late twentieth early twenty-first century. Namely, in the views of J. Deleuze and F. Guattari, where man is, above all, a "desire machine", which focuses mainly on the perception of mainly somatic and libidinal energies. Today, sexual looseness flourishes almost completely in all conceivable and unconceivable forms, both in reality and in art:its presence takes place in all types and genres of art, from elite creativity and "advanced art activity" to the most low-quality pornography.Taking into account the works of "actual" art, we can observe that consciously or subconsciously lost all or part of spirituality, any involvement (sacred, symbolic, pictorial and expressive) in the sphere of the Spirit.They have won some specific extraspiritual energy, which gives nothing to the contemplative vision of man and his spiritual insight,but "... is perceived by almost all human senses, its psychophysiological sphere and often its mind.Conditionally, it (energy) can be designated as "somatic" in the broadest sense of the word" [12:89].

Modern cultural practice also sacralizes "thing" and "everyday life" as an ordinary, routine, significant part of human life, which by virtue of its triviality, monotonous utilitarianism, automatism, gray-mundaneness and monotony remains virtually unnoticed by man himself, is not fixed by consciousness. The very fact of almost ritual, respectful attitude to any and every fragment of everyday life, to the wreckage of any everyday thing. It was found by the artist in a landfill and reverently introduced into the art space of a museum or gallery.It is sacralized, and now it begins to penetrate into the spiritual world of man, representing a kind of "pantheistic materialism", 
displacing from there almost all traditional values - from elementary ethical and religious norms, concepts and ideas to God himself. Such a "reductionist" concept of contemporary art presupposes and provides an opportunity to penetrate into a real extracultural, inhuman reality.

Spiritual culture in the discourse of the modern world is characterized by an increase in its crisis and has a mosaic character, due to the loss of all values, the cultivation of hedonistic individualism in custom, the collapse of sexual morality, the victory in the tastes and ideals of eclecticism. And the destructive influence of market relations leads to the replacement of ideals by business interests. Therefore, it is not surprising that art often cultivates everything low, inhumane, systematically appeals to primitive animal instincts, using usually suppressed by culture mechanisms of the subconscious, which destructively affect the individual.It sacralizes low somatic, libidinal phenomena, thus expressing aesthetic consumer hedonism.

Conclusions. Thus, we can say that one of the main reasons for a number of global changes in modern culture and postmodern art is the leveling and desacralization of traditional spiritual values, which we are witnessing today. Modern cultural and historical situationactualizes the search for a spiritual basis - a guarantor of stability and confidence, which determines the essence of sacred action as the production of the sphere of invariant timeless symbolic images of spiritual life.However, this requires a spiritual vertical, and a central axis that can provide a truly spiritual vector to individual multidirectional experiments and searches.This axis is the sacred "higher Vertical", able to integrate the fragmentary and mosaic of human consciousness, human culture through their focus on Integrity and Eternity. It is on the basis of this nutritious source that the actualization of the sacred phenomenon in modern culture and art is possible. As for re-sacralization in art, it takes the form of shamanism and tries to find transcendent experience in the unconscious, somatic and materialeveryday worlds, introducing into the sphere of the sacred everyday human, often low, values and phenomena. And this is not only a problem of contemporary art, but also of society in general, which should be defined as a problem of spiritual and social pandemic, much more destructive and painful biological.

\section{LITERATURE}

1. Мещенко А. Коеволюційні процеси у християнському сакральному мистецтві: [монографія]. Херсон: Айлант, 2016. 348 с.

2. Сафонова А. Сакральное как социокультурный феномен: автореф. дисс. ... к. филос. н. СПб., 2007. 20 с.

3. Еліаде М. Священне i мирське. Міфи, сновидіння і містерії. Мефістофель і андрогін. Окультизм, ворожбитство та культурні уподобання. Київ.: Вид-во Соломії Павличко "Основи", 2001. 591 с.

4. Бычков В. Феномен неклассического эстетического сознания // Вопросы философии. 2003. № 10. С. 61-71.

5. Ивановская О. Вера как феномен культуры. Дисс. ... д. филос. н.: 24.00.01. Волгоград, 2012. 360 с.

6. Васильева Е. Василий Кандинский. Заклинатель будущего // Искусство. Тайна. 2013. № 2 (585). С. 126-129.

7. Штейнер А. Онтология тайны в искусстве середины века // Искусство. Тайна. 2013. № 2 (585). С. 60-71.

8. Подорога В. Тайны в искусстве нет // Искусство. Тайна. 2013. № 2 (585). C. $18-22$.

9. Степанова С. Русская живопись в контексте десакрализации искусства // Искусствознание. 2006. № 2/06. С. 152176. 
10. Bonnet A.-M. Kunst der Moderne. Kunst der Gegenwart. Herausforderung und Chance. Köln, 2004. 160 s.

11. Савкина А. Понятие сакрального в условиях современного общества: автореф. дисс. ... к. филос. н. М., 2012. 22 с.

12. Бычков В. Феномен неклассического эстетического сознания // Вопросы фимософии. 2003. № 12. С. 80-92.

13. Poetter J. Kunst im 20. Jahrhundert: Schnellkurs. Köln, 2004. 240 s.

\section{REFERENCES (TRANSLATED \& TRANSLITERATED)}

1. Leshchenko, A. (2016). Koyevolyutsyni protsesi u khristiyans'komu sakral'nomu mistetstvii [Coevolutionary processes in Christian sacred art]. Kherson: Aylant (in Ukrainian).

2. Safonova, A. (2007). Sakral'noye kak sotsiokul'turnyy fenomen [Sacred as a sociocultural phenomenon]. Avtoref. diss. ... k. filos. n. SPb (in Russian).

3. Yeliade, M. (2001). Svyashchenne $i$ mirs'ke. Mifi, snovidinnya i misterii. Mefistofel' $i$ androgin. Okul'tizm, vorozhbitstvo ta kul'turni Upodobannya. [Sacred and secular. Myths, dreams and mysteries. Mephistopheles and androgyne. Occultism, divination and cultural preferences]. Kiyv: Vid-vo Solomii Pavlichko "Osnovi" (in Ukrainian).

4. Bychkov V. (2003). Fenomen neklassicheskogo esteticheskogo soznaniya. [The phenomenon of non-classical aesthetic consciousness]. Voprosy filosofii, 10, 61-71 (in Russian).

5. Ivanovskaya O. (2012). Vera kak fenomen kul'tury. [Faith as a cultural phenomenon]. Avtoref. diss. ... d. filos. $\mathrm{n}$. Volgograd (in Russian).

6. Vasil'yeva, Ye. (2013). Vasiliy Kandinskiy. Zaklinatel' budushchego [Vasily
Kandinsky. The caster of the future]. Iskusstvo. Tayna, 2 (585), 126-129 (in Russian).

7. Shteyner, A. (2013). Ontologiya tayny $\mathrm{v}$ iskusstve serediny veka [Ontology of mystery in the art of the middle of the century]. Iskusstvo. Tayna, 2 (585), 60-71 (in Russian).

8. Podoroga, V. (2013). Tayny v iskusstve net [There are no secrets in art]. Iskusstvo. Tayna, 2 (585), 18-22 (in Russian).

9. Stepanova, S. (2006). Russkaya zhivopis' v kontekste desakralizatsii iskusstva [Russian painting in the context of desacralization of art]. Iskusstvoznaniye, 2/06, 152-176 (in Russian).

10. Bonnet, A.-M. (2004). Kunst der Moderne. Kunst der Gegenwart. Herausforderung und Chance [Modern Art. Contemporary art. Challenge and opportunity]. Koln (in Germany).

11. Savkina, A. (2012). Ponyatiye sakral'nogo $v$ usloviyakh sovremennogo obshchestva [The concept of the sacred in modern society]. Avtoref. diss. ... k. filos. n. M. (in Russian).

12. Bychkov, V. (2003). Fenomen neklassicheskogo esteticheskogo soznaniya [The phenomenon of non-classical aesthetic consciousness]. Voprosy filosofii, 12, 80-92 (in Russian).

13. Poetter, J. (2004). Kunst im 20. Jahrhundert: Schnellkurs [Art in the 20th Century: Quick Course]. Koln (in Germany).

Receive: March 18, 2020 Accepted: May 20, 2020 